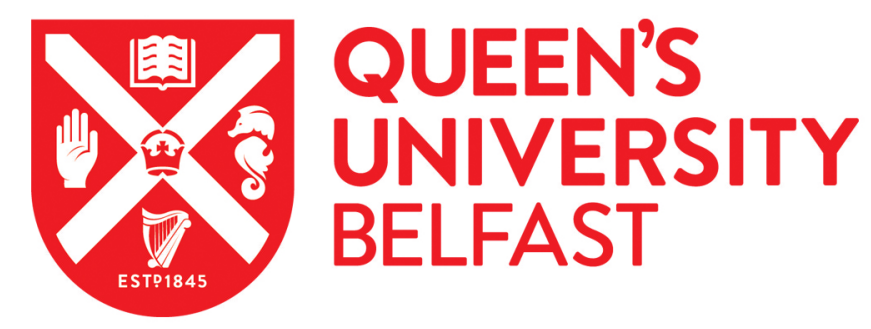

\title{
Meaningful and Effective? Considering Victims' Interests Through Participation at the International Criminal Court
}

Moffett, L. (2015). Meaningful and Effective? Considering Victims' Interests Through Participation at the International Criminal Court. Criminal Law Forum, 26(2), 255-289. https://doi.org/10.1007/s10609-015-9256-1

\author{
Published in: \\ Criminal Law Forum
}

Document Version:

Early version, also known as pre-print

Queen's University Belfast - Research Portal:

Link to publication record in Queen's University Belfast Research Portal

Publisher rights

Copyright 2015 The Author

The final publication is available at Springer via http://dx.doi.org/10.1007/s10609-015-9256-1

\section{General rights}

Copyright for the publications made accessible via the Queen's University Belfast Research Portal is retained by the author(s) and / or other copyright owners and it is a condition of accessing these publications that users recognise and abide by the legal requirements associated with these rights.

Take down policy

The Research Portal is Queen's institutional repository that provides access to Queen's research output. Every effort has been made to ensure that content in the Research Portal does not infringe any person's rights, or applicable UK laws. If you discover content in the Research Portal that you believe breaches copyright or violates any law, please contact openaccess@qub.ac.uk. 


\title{
Meaningful and effective? Considering victims' interests through participation at the International Criminal Court
}

\begin{abstract}
The Rome Statute of the International Criminal Court have been lauded for its innovative victim provisions, but over ten years of practice of the Court how effective have these provisions been in considering victims' interests? This article examines the extent to which victims' interests are considered before the International Criminal Court (ICC) through their participation in proceedings in light of victimology and human rights law. This article begins by critically analysing the extent to which victims' procedural role in presenting their interests are taken into account by the ICC in determining outcomes by examining some recent decisions and judgments by the Court. Of particular interest is the contest between victims' interests and the role of the Prosecutor in pivot parts of the proceedings including the investigation, trial, sentencing, and reparations. While the Court continues to develop the victim participation regime, this article identifies that in judicial decision making victims' interests are not sufficiently taken into account, and as a result the outcomes of the ICC are unlikely to satisfy victims who come before it.
\end{abstract}

\section{A. Introduction}

At the opening of the Rome Conference on the Statute of the International Criminal Court UN Secretary General Kofi Annan stressed to delegates that the 'overriding interests must be that of the victims and the international community as a whole'. ${ }^{1}$ The resulting victim provisions within the Rome Statute include a number of provisions for victims including recognition, participation, protection, reparations and a Trust Fund. The inclusion of these provisions has been declared a 'high-water mark ${ }^{2}$ by placing victims at the 'heart of international criminal justice'. ${ }^{3}$ Yet after fifteen years since the Rome Statute was adopted and ten years of practice of the International Criminal Court (ICC) it is questionable the extent to which an international criminal justice mechanism, which purpose is to prosecute and punish perpetrators of international crimes, can be amenable to the interests of victims. While this issue has been received a great deal of attention from commentators, and numerous decisions by the ICC in working out its practice in reality, there has been little analysis as to the impact victims' interests are having on judicial decision making.

\footnotetext{
${ }^{1}$ UN Secretary-General declares overriding interest of international criminal court conference must be that of victims and world community as a whole, Press Release L/ROM/6.r, 15 June 1998.

${ }^{2}$ Christine Chung, Victims' Participation at the International Criminal Court: Are Concessions of the Court Clouding the Promise? Northwestern Journal of International Human Rights 6(3) (Spring 2008) 459-545, p516.

${ }^{3}$ Paolina Massidda and Sarah Pellet, Role and practice of the Office of Public Counsel for Victims, in C. Stahn and G. Sluiter (eds.), The Emerging Practice of the International Criminal Court, (Brill 2009) 691-706, p692.
} 
This article explores the role of victims in the criminal proceedings of the International Criminal Court and the extent to which their interests have impacted upon the ICC judges' decision making in light of human rights law and victimological theorisation. The article begins by first outlining how victims' interests can be considered in international criminal proceedings, before contrasting this role with the purpose of international criminal justice. The second part of this article examines victim participation within the ICC, and how this has affected judicial decision making to assess its effectiveness. This article finds that at the ICC, despite innovative victim provisions, victims' interests have little impact on outcomes of the Court. Instead in order to ensure the Court is more responsive to victims understanding of justice it should give greater weight to their interests, which in turn is likely to improve their satisfaction with the ICC, as well as public confidence and legitimacy of the work of the Court.

\section{B. The Role of Victims in International Criminal Justice}

\section{Considering victims' interests}

Strictly defined, to consider means to 'view or contemplate attentively, to survey, examine, inspect, scrutinize. ${ }^{4}$ Considering victims' interests has been explained as 'the taking into consideration of the views and concerns of victims in the course of the judicial process' ${ }^{5}$ As victims suffer harm as a result of crimes it is accepted that they have interests in criminal proceedings against those responsible. How victims' interests are considered is dependent on the procedural rules to which they can represent their views and concerns, as well as more substantively in how those interests are considered by decision makers, in the case of the courts, judges. Accordingly, the consideration of victims' interests in these areas can be distilled down to two notions of procedural and substantive justice for victims. ${ }^{6}$ Procedural justice entails fairness of treatment in processes. With regards to victims this involves their participation in proceedings, impact on decisions, and ability to shape outcomes. ${ }^{7}$ Treating victims with respect can improve their satisfaction with criminal proceedings. ${ }^{8}$ Substantive justice refers to the outcomes of judicial mechanisms. For victims this involves redressing their harm and the causes of victimisation, giving rise to three main rights in relation to outcomes: truth; justice; and reparations. ${ }^{9}$ Together

\footnotetext{
${ }^{4}$ English Oxford Dictionary (OUP 2013).

${ }^{5}$ Separate Opinion of Judge Pikis, Prosecutor v Lubanga, Decision of the Appeals Chamber on the Joint Application of Victims a/0001/06 to a/0003/06 and a/0105/06 concerning the "Directions and Decision of the Appeals Chamber” of 2 February 2007 ICC-01/04-01/06-925, 13 June 2007, para.14.

${ }^{6}$ See Luke Moffett, Justice for Victims before the International Criminal Court, (Routledge 2014).

${ }^{7}$ Jo-Anne Wemmers, Victims in the Criminal Justice System, (Kugler 1996); and Yael Danieli, Massive Trauma and the Healing Role of Reparative Justice, in R. Letschert, R. Haveman, A.M. de Brouwer, and A. Pemberton (eds.), Victimological Approaches to International Crimes: Africa, (Intersentia 2011), 235-261.

${ }^{8}$ Brianne McGonigle Leyh, Procedural Justice? Victim Participation in International Criminal Proceedings (Intersentia, 2011), p48.

${ }^{9}$ Based on the right to an effective remedy under Article 8 Universal Declaration of Human Rights (UDHR), 217 A (III), 10 December 1948; Article 13 European Convention for the Protection of Human Rights and Fundamental Freedoms (ECHR), CETS No.5; and Article 2(3) International Convention of Civil and Political Rights, UN Treaty Series Vol.999, p171, 16 December 1966. Velásquez Rodríguez v Honduras, Judgement, Series C No.7
} 
procedural and substantive justice complement each other to ensure a more effective remedy for victims’ harm.

Participation enables victims to present their interests in judicial proceedings so that they have an impact on judges' decision making process, which in turn can help to ensure outcomes more effectively respond to their needs. Although allowing victims to express their needs and interests is important, it does not require their views to dominate judges' decisions, just that they are considered and taken into account in determining justice. ${ }^{10}$ Thus the consideration of victims' interests is supposed to improve the responsiveness of a justice mechanism to victims' needs, which can be reflected through compromise with other parties' interests. ${ }^{11}$

The inclusion of victim participation within international criminal proceedings is not without precedent. The protection of victims' interest has been growing both nationally and internationally over the past few decades, with the development of certain minimum guarantees for their fair treatment in criminal proceedings and in the aftermath of gross violations of their rights. ${ }^{12}$ A number of national jurisdictions include victim participation in criminal proceedings in order to protect their interests. In civil law countries victims have a wide range of participatory rights in criminal proceedings, such as partie civile ${ }^{13}$ and Nebenklage. ${ }^{14}$ Additionally, victims in Islamic law countries have the right to prosecute privately an offender and to claim compensation. ${ }^{15}$ To lesser extent, some common law countries allow victims to bring private prosecutions and make impact statements during sentencing. ${ }^{16}$

(IACtHR, 29 July 1988), paras.174-175; Aksoyv. Turkey, App no 21987/93 (ECtHR, 18 December 1996), para.98. These rights are supported by victimological research of conflict situations on victims' needs, see Ernesto Kiza, Corene Rathgeber, and Holger Rohne, Victims of War: War-Victimization and Victims' Attitudes Towards Addressing Atrocities, (Hamburger Edition 2006); Wemmers n.7, p148; and See M. Cherif Bassiouni, International Recognition of Victims’ Rights, Human Rights Law Review 6 (2006) 203-279.

${ }^{10}$ Wemmers n.7, p146-147.

${ }^{11}$ Principle 6(b), UN Victims’ Declaration.

12 See Marion E. Brienen and Earnestine H. Hoegen, Victims of Crime in 22 European Justice Systems, (Wolf Legal 2000). UN Declaration of Basic Principles of Justice for Victims of Crime and Abuse of Power, A/RES/40/34, 29 November 1985 (the UN 'Victims’ Declaration’); and UN Basic Principles and Guidelines on the Right to a Remedy and Reparation for Victims of Gross Violations of International Human Rights Law and Serious Violations of International Humanitarian Law, A/RES/60/147, 16 December 2005 (UNBPG).

${ }^{13}$ The partie civile procedure in French-speaking countries victims can initiate prosecutions, participate as a party in proceedings, and to bring ancillary claims for damages on the prosecution's case. See Articles 52, and 706-42 of the French Criminal Code; and Articles 85-91, 371-375 and 418-426 of the French Code of Criminal Procedure. See Jonathan Doak, Victims' rights, human rights and criminal justice: Reconceiving the role of third parties, (Hart 2008), p310.

${ }^{14}$ In the German-speaking countries under the Nebenklage procedure victims can appoint their own counsel to act as a private accessory prosecutor, who can inspect files, present their case in a trial, question witnesses, object to judges' orders and questions, apply for evidence to be taken and make statements. Section 397 and 403-406 of the Strafprozessordnung of the German Criminal Code.

15 Hossein Esmaeili, and Jeremy Gans, Islamic Law across Cultural Borders: The Involvement of Western Nationals in Saudi Murder Trials, Denver Journal of International Law and Policy 28 (1999-2000) 145-174, p149150.

${ }^{16}$ In the United Kingdom, Section 6 of the Prosecution of Offences Act 1985 governs private prosecutions; for a discussion on the UK and USA see Doak n.13, p125-126. 
Victim participation is also included in the international criminal justice hybrid tribunals of the Special Tribunal for Lebanon ${ }^{17}$ and the Extra-Ordinary Chambers of the Courts of Cambodia (ECCC). At the ECCC, victims can participate by requesting a specific investigation, appealing decisions, and they are not required to evidence their 'personal interests' in order to participate. ${ }^{18}$ Victims at the ECCC are organised similarly to the ICC through collective civil parties being represented by a single lawyer, but it also allows a group of them to form victim associations to facilitate collective participation. ${ }^{19}$ The integration of victim participation in these different mechanisms indicates its emerging normative nature in international criminal justice.

\section{Harmonising interests and achieving victim-orientated justice}

At first glance the protection of victims' interests seems unnecessary in international criminal justice, as its primary goal is to prosecute and punish perpetrators of international crimes. This retributive nature of international criminal justice could be seen to be inconsistent with victims' interests in justice, which has been classified as more remedial or reparative justice. ${ }^{20}$ Furthermore, the proceedings of international criminal justice mechanisms follow a two-party adversarial contest over evidence, leaving little room for victims as third parties to participate without undermining the rights of the other parties.

Nonetheless, the inclusion of victims' interests in international criminal justice mechanisms is important for a number of reasons. First, victims are important actors in the success of international criminal justice mechanisms. They are essential in proving the occurrence of such crimes by testifying and giving evidence to assist investigations and prosecutions. In order to achieve this, providing sufficient protection of their rights is justified to build a sense of trust between the victims and the international criminal justice mechanisms so as to facilitate their proactive co-operation. Second on a moral basis, as criminal courts are concerned with adjudicating on crimes, it is considered unjust that victims, as those most affected by crimes, can have their needs and interests ignored in the determination of justice. ${ }^{21}$ Victims' rights are meant to ensure justice mechanisms are responsive to their needs and consider their input into proceedings so as to remedy their harm. This resonates well with the theory of procedural justice as well as improving the legitimacy of such institutions in the eyes of those most affected by international crimes.

\footnotetext{
${ }^{17}$ Article 17, Statute for the Special Tribunal for Lebanon (STL), which adopts a similar victim participation provision to the Rome Statute's Article 68(3). See Rules 86-87 in the STL Rules of Procedure and Evidence, 8 February 2012, STL/BD/2009/01/Rev. 4; and Jérôme de Hemptinne, Challenges Raised by Victims’ Participation in the Proceedings of the Special Tribunal for Lebanon, Journal of International Criminal Justice 8(1) (2010) 165-179.

${ }^{18}$ Rules 23bis, 55(10), 74(4), 80(2), of the ECCC Internal Rules. See McGonigle n.8.

${ }^{19}$ Rules 23 ter and quater, ECCC Internal Rules.

${ }^{20}$ See Danieli n.6.

${ }^{21}$ William Tallack, Reparation to the Injured and the Right of the Victims of Crime to Compensation, (London 1900); and Margaret Fry, Justice for Victims, Journal of Public Law 8 (1959) 191-194.

${ }^{21}$ See John D. Jackson, Justice for All: Putting Victims at the Heart of Criminal Justice? Journal of Law and Society 30(2) (2003) 309-326.
} 
Even so, there are other interests involved in the prosecution and punishment of international crimes besides victims. State parties and the international community have an interest in maintaining the status quo of international criminal law by holding those most responsible to account, as well as ensuring a fair and impartial trial for defendants. As May states, 'victims are not owed convictions; rather it is the larger society, if anyone, that has the right to pursue convictions. ${ }^{22}$ The individual rights of victims are not thus determinative of justice traditionally in international criminal justice mechanisms. This is evident with past international criminal tribunals, which relegated victims' role to just witnesses, with no opportunity to present their interests in proceedings due to fears it would undermine the rights of the defendant. ${ }^{23}$ An exception to this was with the provision of victim-impact statements during sentencing in the International Criminal Tribunal for the former Yugoslavia. ${ }^{24}$ However, these statements aligned victims' interests with the pursuit of retributive justice by imposing a harsher sentence on the accused, rather than a broader notion of justice for victims. Furthermore, 'justice for victims' was often invoked as rhetoric by the Tribunals to justify punishment and to legitimise their existence.

As such, victims in the international criminal tribunals were considered as objects, in the sense that justice is done on the basis of their suffering, without recognising them as subjects having needs and interests in determining the substantive outcomes. ${ }^{25}$ The experience of the ad-hoc tribunals, while disappointing for victims in having their interests considered, revealed the difficulties in incorporating them into international criminal proceedings. In light of this the drafters of the Rome Statute of the International Criminal Court intended to offer 'justice to victims', by achieving a more effective balance between the parties, reflecting victimological and human rights developments. ${ }^{26}$ This 'balance' has been constructed more at the potential conflict in interests between the defendant and victims, whereby the right to victims to participate cannot be 'prejudicial or inconsistent with the rights of the accused', giving preference to the defendant, due to their presumption of innocence and risk of facing punishment if convicted. ${ }^{27}$

\footnotetext{
${ }^{22}$ Larry May, Crimes against Humanity, (CUP 2005), p220.

${ }^{23}$ See Letter dated 12 October 2000 from the President of the International Tribunal for the Former Yugoslavia addressed to the Secretary-General, S/2000/1063, 3 November 2000; and Letter dated $9^{\text {th }}$ November 2000 from the President of the International Criminal Tribunal for Rwanda addressed to the Secretary-General, S/2000/1198 15 December 2000.

${ }^{24}$ For instance see Prosecutor v Tadić, Sentencing Judgement, IT-94-1-T, 14 July 1997, paras.4 and 56.

${ }^{25}$ Claude Jorda and Jérôme de Hemptinne, The Status and Role of the Victim, in A. Cassese, P. Gaeta, and R.W. Jones (eds.), The Rome Statute of the International Criminal Court: A Commentary, (OUP 2002) 1387-1419, p1389.

${ }^{26}$ See the speech by Fiona McKay, Redress, on behalf of the Victims Rights Working Group at the Rome Conference, 16 June 1998; and Christopher Muttukumaru, Reparations to Victims, in Roy S Lee (ed.), The International Criminal Court: The making of the Rome Statute; Issues, negotiations, results, (Kluwer 1999) 262270, p264; and Yael Danieli, Report of the Victims' Rights Working Group, Rome Conference 15 June - 17 July 1998, p3.

${ }^{27}$ Article 68(3), Rome Statute.
} 
This balanced approach is derived from human rights law. The European Court of Human Rights has held that victims have distinct interests in criminal proceedings, as they 'cannot be regarded as either the opponent - or for that matter necessarily the ally - of the prosecution, their roles and objectives being clearly different. ${ }^{, 28}$ In addition, the European Court has found that in order to ensure a fair and impartial trial the rights of the defendant have to be balanced against those of the victims. ${ }^{29}$ As such, the right to a fair trial is not limited to protecting the rights of defendants, but also victims' role and interests in proceedings. That said, victims' procedural rights can be qualified, and made malleable to the defendant's rights and public interests. Nor are victims' interests absolute, by way of example, the consideration of their interests by a court does not give them a right to obtain a certain outcome, such as prosecution or conviction. ${ }^{30}$ Instead victim-orientated justice requires that victims' interest to see perpetrators are held to account is considered, reflecting human rights protections of their more substantive rights to life, freedom from ill-treatment and privacy. This rights discourse in determining fairness in proceedings can provide a common language to balance differing interests, rather than allowing the interests of one party to trump others. ${ }^{31}$ This interpretative balance better reflects fairness for all parties before a criminal court, rather than focusing exclusively on the defendant. ${ }^{32}$ By balancing rights, human rights law makes criminal justice more victim-orientated justice.

At first glance enabling victims to participate in international criminal justice would indicate a broader construction of justice than retribution, towards more procedural and reparative justice. Funk and Guhr suggest that restorative justice encouraged the shift towards incorporating victims within the ICC. ${ }^{33}$ The inclusion of participation, reparations and a Trust Fund indicates that the Court does not strictly follow a retributive justice approach, but seeks to restore victims. However in contrast to the informal nature of restorative justice, the proceedings of the ICC are 'lawyer dominated', and retain a retributive focus, limiting victims' interests as participants in deference to the two parties of the prosecution and the defence. ${ }^{34}$ Moreover, given the scale and the ideology which drives international

\footnotetext{
${ }^{28}$ Berger v France, App No. 48221/99, (ECtHR, 3 December 2002), para.38; and Perez v France, App No 47287/99, (ECtHR, 12 February 2004), para.68.

${ }^{29}$ Doorson $v$ the Netherlands, App no. 20524/92 (ECtHR, 26 March 1992). para.70.

${ }^{30}$ Öneryildiz v Turkey, App no. 48939/99, (ECtHR, 30 November 2004), para.96; and Giuliani And Gaggio v Italy (Application no. 23458/02) (Grand Chamber), 24 March 2011, para.306. A similar position is found by the Human Rights Committee in Arhuaco v Colombia, Views on Communication No. 612/1995, CCPR/C/60/D/612/1995, $29^{\text {th }}$ July 1997.

${ }^{31}$ See Michael Ignatieff, Human Rights as Politics and Idolatry, Princeton University Press (2003), p20-21.

${ }^{32}$ Doorson v the Netherlands, para.70; Gäfgen v Germany, (Application no. 22978/05), 1 June 2010, para.175; and Al-Khawaja and Tahery $v$ The United Kingdom, (Applications nos. 26766/05 and 22228/06), 15 December 2011, para.118.

${ }^{33}$ T. Markus Funk, Victims' Rights and Advocacy at the International Criminal Court (OUP 2010), p4; and A.H. Guhr, Victim Participation During the Pre-Trial Stage at the International Criminal Court, International Criminal Law Review 8(1-2) (2008) 109-142, p110.

${ }^{34}$ Doak n.13, p221.
} 
crimes, ${ }^{35}$ restorative justice may be inappropriate as it 'is a relatively narrow concept that requires dialogue between the offender and the victim. ${ }^{36}$

Instead the drafting of the Rome Statute and the jurisprudence of the ICC have been more influenced by UN Victims' Declaration and human rights law than restorative justice. ${ }^{37}$ As Vasiliev asserts, rather than making the Court a restorative justice forum where victims can interact with the perpetrator and collectively resolve their differences, the Court evinces victim-orientated justice without replacing its core retributive goal of prosecuting and punishing perpetrators of international crimes. ${ }^{38}$ Vasilev has more recently suggested that the Court should free itself from this 'restorative complex', which should instead be limited to reparations. ${ }^{39}$ While the ICC may be more victim-orientated with the inclusion of provisions such as victim participation, this article argues that the Court remains a focused on prosecuting and punishing perpetrators, but it could be more responsive to victims' interests, without adopting a restorative approach or losing sight of its retributive purpose.

Victim-orientated justice would reflect victims' interests in procedural and substantive justice dimensions, by enabling victims to participation and ensuring that such interests are considered in decision making. As such, to effectively consider victims' interests, we must understand their perspective, while not having the Court to adopt it as its own, it requires victims to voice their interests, so that their input adds or improves comprehension of their viewpoint in order to deliver justice. Otherwise the ICC and future mechanisms reinforce the abstract paternalistic international justice, whereby victims are invoked symbolically so as to legitimise international prosecutions. ${ }^{40}$ This distance from the Court can be perceived domestically by those affected by international crimes as illegitimate and undemocratic, as well as potentially undermining individual's autonomy and dignity to seek their own redress on their terms.

While much has been written on the conflict between victims and the rights of defendants, perhaps an issue overlooked by many commentators is how potential conflicts between the Prosecutor and the victims are to be 'balanced' by the Court's judges. Although victims can participate in the proceedings of the international criminal justice mechanisms, it is very much tempered by the role of the Prosecutor in selecting charges and the availability and reliability of evidence, as well as the rights of the defendant and concerns of expediency and resources. It should be noted from the outset, before

\footnotetext{
35 See Moffett n.6, p10-12.

${ }^{36}$ Carolyn Hoyle, Can International Justice be Restorative Justice? The Role of Reparations, in N. Palmer, P. Clark and D. Granville (eds), Critical Perspectives in Transitional Justice (Intersentia, 2012) 189-210, at 192193.

${ }^{37}$ See Carsten Stahn, Hector Olásolo, and Kate Gibson, Participating of Victims in pre-trial proceedings of the ICC, Journal of International Criminal Justice 4(2) (2006) 219-238, p220-221; William A. Schabas, An Introduction to the International Criminal Court, (CUP 2011), p327.

${ }^{38}$ Sergey Vasiliev, Article 68(3) and personal interests of victims in the emerging practice of the ICC, in C. Stahn and G. Sluiter (eds.), The Emerging Practice of the International Criminal Court, (Brill 2009) 635-690, p677.

${ }^{39}$ Sergey Vasiliev, Victim Participation Revisited: What the ICC is Learning About Itself, in C. Stahn (ed.), The Law and Practice of the International Criminal Court (OUP 2014) (forthcoming).

${ }^{40}$ See Sara Kendall and Sarah Nouwen, Representational Practices at the International Criminal Court: The Gap between Juridified and Abstract Victimhood, Law and Contemporary Problems 76(3) (2014), 235-262.
} 
examining the practice of the ICC, that accountability and truth in a criminal trial is necessarily linked to the charges and perpetrators brought before it, and its procedural and evidential rules. Consequently, international criminal justice can only offer partial truth and justice to the few victims who are lucky to appear before them. ${ }^{41}$ What is important here is to recognise such limits, and to construct expectations of the ICC in such a frame, while at the same time pushing the internal boundaries of the Court to deliver justice to those victims before, and externally in encourage State Parties to complement the Court in delivering justice to all victims of international crimes. ${ }^{42}$

\section{Considering the interests of victims at the International Criminal Court}

The general provision for victim participation under the Rome Statute is Article 68(3), ${ }^{43}$ which stipulates that,

'Where the personal interests of the victims are affected, the Court shall permit their views and concerns to be presented and considered at stages of the proceedings determined to be appropriate by the Court and in a manner which is not prejudicial to or inconsistent with the rights of the accused and a fair and impartial trial. Such views and concerns may be presented by the legal representatives of the victims where the Court considers it appropriate ... [emphasis added]'

The Court, adopting the jurisprudence of the regional human rights courts, has found that victims' interests are affected in criminal proceedings against the accused owing to their rights to truth and justice. ${ }^{44}$ For victim participation at the ICC, as there are potentially millions of victims within the jurisdiction of the Court, who cannot all personally participate in proceedings, participation is instead carried out through victims' legal representatives (VLRs). ${ }^{45}$ VLRs are meant to facilitate the communication of victims' interests to the ICC, so that it can tailor proceedings, measures and, more generally, justice to their needs. ${ }^{46}$ As such, VLRs are able to participate in proceedings before the Court where victims' personal interests are affected. ${ }^{47}$ Access to legal assistance or representation can more effectively translate and advocate victims' interests and needs into legal processes by lawyers

\footnotetext{
${ }^{41}$ Marc S. Groenhuijsen and Antony Pemberton, Genocide, Crimes Against Humanity and War Crimes: A Victimological Perspective on International Criminal Justice, in Letschert et al, n.6, p17.

${ }^{42}$ See Moffett n.6, Chapter 6.

${ }^{43}$ Victims can participate at the ICC under Articles 15(3), 19(3), 68(3) and 75(3), Rome Statute.

${ }^{44}$ Prosecutor v Katanga and Chui, Decision on the Set of Procedural Rights Attached to Procedural Status of Victim at the Pre-Trial Stage of the Case ICC-01/04-01/07-474, 13 May 2008, para.31-44; Prosecutor $v$ Bemba, Fourth Decision on Victims' Participation, ICC-01/05-01/08-320, 12 December 2008; Prosecutor v Abu Garda, Decision on the 34 Applications for Participation at the Pre-Trial Stage of the Case, ICC-02/05-02/09-121, 29 September 2009, para.3; Prosecutor v Al Bashir, Decision on Applications a/0011/06 to a/0013/06, a/0015/06 and a/0443/09 to a/0450/09 for Participation in the Proceedings at the Pre-Trial Stage of the Case, ICC-02/05-01/0962, 15 December 2009, para.4-5.

${ }^{45}$ Article 68(3), and Rules 90-92. Chung n.2, p525.

${ }^{46}$ McGonigle n.8, p359.

${ }^{47}$ Article 68(3).
} 
independent of the prosecution, who can often overlook victims' interests as they also have to represent public interests. ${ }^{48}$

The proceedings of the Court are distinguishable from previous tribunals, because of the physical presence of VLRs voicing victims' views and concerns. For instance, in the first case before the Court of Thomas Lubanga, the VLRs at the beginning of the trial discussed the charges against the accused, as well as the expectations and experiences of the victims they represented. ${ }^{49}$ In order to present victims' 'views and concerns' the Court has established that VLRs can participate in eight ways: to attend hearings; make oral motions, responses, and submissions; file written submissions; access evidence; ask questions; submit evidence; call witnesses; and to be notified. ${ }^{50}$ These modalities are discretionary owing to the protection of other interests before the Court, such as the rights of the defendant, meaning that victims do not automatically have the right to participate. That said, there remains stark disagreements within different Chambers of the ICC as to how to interpret and apply Article 68(3) and effectuate victim participation, despite the dearth of case law. For instance in recent decisions by different chambers victims' participatory 'rights' have been distinguished in the Ntaganda and the Banda cases. In the Ntaganda case victim participation is limited to attendance and participation in proceedings, access to public records, notification of filings and decisions, and filing of written submissions. ${ }^{51}$ Whereas in the Banda case make requests to call witnesses, present evidence, challenge the relevance or admissibility of evidence submitted by other parties, question witnesses, access confidential filings, and participate in closed and ex parte hearings. ${ }^{52}$ It is apparent that victims in the Banda case have a more substantial role in proceedings, effectively a party in proceedings, in contrast to victims in the Ntaganda case have a more amicus curiae role. ${ }^{53}$

The interpretation and practice of victim participation gives rise to a number of other challenges as to the extent to which the Court can be responsive to victims' interests. While victims can have their interests considered under a number of provisions and proceedings in the Rome Statute, the rest of this article focuses on victims' participation in the investigation, trial, sentencing, and reparations stage,

\footnotetext{
${ }^{48}$ Emily Haslam, Victim Participation at the International Criminal Court: A Triumph of Hope over Experience, in D. McGoldrick (ed.), The Permanent International Criminal Court, (Hart 2004), p315-334, p320.

${ }^{49}$ See Prosecutor v Lubanga, ICC-01/04-01/06-T-107-ENG, 26 January 2009.

50 Rules 91-92, and 144. See Lubanga, ICC-01/04-01/06-1119; Katanga and Chui, ICC-01/04-01/07-474; Katanga and Chui, Decision on the Modalities of Victim Participation at Trial, ICC-01/04-01/07-1788, 22 January 2010; and Bemba, ICC-01/05-01/08-320.

${ }^{51}$ Prosecutor v Bosco Ntaganda, Decision on Victims' Participation at the Confirmation of Charges Hearing and in the Related Proceedings, ICC-01/04-02/06-211, 15 January 2014, paras.85-96.

52 Prosecutor $v$ Abdallah Banda, Decision on the participation of victims in the trial proceedings, ICC-02/0503/09-545, 20 March 2014, paras.24-41.

${ }^{53}$ A possible explanation between these two cases could be that the Ntaganda case is at the pre-trial stage, whereas the Banda case is at the trial stage. Though such distinctions between pre-trial and trial have not been so marked. Cf. Prosecutor v Lubanga, Decision on victim's participation ICC-01/04-01/06-1119, 18 January 2008, para.12; Prosecutor v Katanga, Decision on the Set of Procedural Rights Attached to Procedural Status of Victim at the Pre-Trial Stage of the Case, ICC-01/04-01/07-474, 13 May 2008; and Prosecutor $v$ Katanga, Judgment on the Appeal of Mr Katanga Against the Decision of Trial Chamber II of 22 January 2010 Entitled 'Decision on the Modalities of Victim Participation at Trial', ICC-01/04-01/07-2288, 16 July 2010, para.48.
} 
owing to these proceedings determining victims' substantive rights to truth, justice and reparations, and the extent to which they have been affected by judges in their decision making. ${ }^{54}$

\section{Participation in the investigation}

The investigation is a significant point in the determination of truth and justice owing to the selection of charges and perpetrators for trial. Victim participation in investigations has long been established by the regional human rights courts as a fundamental part of ensuring its effectiveness and countering impunity. ${ }^{55}$ This position is justified on the ground that the participation of victims as independent parties can provide oversight of prosecutorial discretion in the selection of perpetrators and charges, which can more accurately identify those responsible. ${ }^{56}$ The role of victims in this stage is necessary to safeguard their interests, as well as to provide public scrutiny and accountability. ${ }^{57}$ The Inter-American Court of Human Rights has determined that victims in an investigation should have, 'substantial possibilities of being heard and acting in the respective proceedings, both in order to clarify the facts and punish those responsible, and to seek due reparation. ${ }^{58}$ The European Court has established that victim participation is a procedural right attaching to fundamental rights, such as the right to life. ${ }^{59}$ This includes the modalities of victims being informed of a decision not to prosecute, access to the investigation and case file, including witness statements, and to present their interests. ${ }^{60}$ More recently the European Union has recognised that victims should have a right to review prosecutor's decisions not to prosecute, so as to ensure greater accountability by allowing discretionary decisions to be examined impartially by an independent party. ${ }^{61}$ That being said, victims have no right to claim that a certain person is prosecuted or to obtain a particular outcome such as a conviction; thus a distinction between their procedural right to participate and the absence of a substantive right to a prosecution or conviction. ${ }^{62}$

\footnotetext{
${ }^{54}$ For examination of victims' interests in reparations see Luke Moffett, Reparative complementarity: Ensuring an effective remedy for victims in the reparation regime of the International Criminal Court, International Journal of Human Rights 17(3) (2013) 368-390. For concerns with identifying victims at the ICC see Emily Haslam and Rod Edmunds, Victim Participation, Politics and the Construction of Victims at the International Criminal Court: Reflections on Proceedings in Banda and Jerbo, Melbourne Journal of International Law 14(2) (2013) 727-747.

${ }^{55}$ Particularly with violations of the right to life or prohibition on the use of torture, and inhumane and degrading treatment: Kaya v Turkey, App no 22535/93 (ECtHR 28 March 2000), para.121-126; and Mapiripán Massacre v Colombia, Merits, Reparations and Costs, Series C No 134 (IACtHR, 15 September 2005), paras.116 and 119.

${ }^{56}$ Raquel Aldana-Pindell, An Emerging Universality of Justiciable Victims' Rights in the Criminal Process to Curtail Impunity for State-Sponsored Crimes, Human Rights Quarterly 26 (2004) 605-686, p612.

${ }^{57}$ Oğur v Turkey, App no 21594/93 (ECtHR, 20 May 1999), para.92; Güleçv Turkey, App no 21593/93 (ECtHR, 27 July 1998), para.82; and McKerr v the United Kingdom, App no 28883/95, (ECtHR, 4 May 2001), para.148.

${ }^{58}$ Villagrán Morales et al. Case (The "Street Children" Case) v. Guatemala, Reparations, Series C No 63 (IACtHR, 19 November 1999), para.227.

${ }^{59}$ McKerr, para.148.

${ }^{60}$ See n.47.

${ }^{61}$ Article 11, EU Directive 2012/29/EU Establishing minimum standards on the rights, support and protection of victims of crime, 25 October 2012; and $R v$ Killick, [2011] EWCA Crim 1609, para.48-51.

${ }^{62}$ In contrast to many domestic jurisdictions victims cannot bring private prosecutions at the international level, due to the danger of such prosecutions being politically driven, but also the difficulties in collecting such evidence to reasonably secure a conviction, though this could change with technological advances.
} 
At the ICC, the Prosecutor is obligated to consider and respect the interests of victims in investigations under Articles 53(1)(c) and 54(1)(b). The Prosecutor is also obligated to inform victims when deciding not to initiate an investigation or prosecute under Article $53 .{ }^{63}$ Unlike national courts, victims before the ICC have no right to initiate criminal investigations or prosecutions. ${ }^{64}$ Additionally, Article 68(3) does not specify whether they can participate in investigations just in 'proceedings determined to be appropriate by the Court'. In some of the first decisions of the Court, Pre-Trial Chambers I and II found that the investigation is an appropriate proceeding in which victims can participate. ${ }^{65}$ Pre-Trial Chamber I recognised that they are important in an investigation, 'to clarify the facts, to punish the perpetrators of crimes and to request reparations for the harm suffered. ${ }^{66}$ The Chamber further determined that victim participation is not inconsistent or prejudicial to the 'integrity and objective of the investigation' nor to 'efficiency and security'. ${ }^{67}$ Accordingly, VLRs could participate in the investigation provided that they did not give victims access to the record nor adversely affect the Prosecutor's ability to conduct investigations. ${ }^{68}$ They could also present victims' views and concerns to the Chamber, as well as submit evidence to the investigation. ${ }^{69}$ This is in line with the jurisprudence established by the human rights courts.

The Pre-Trial Chambers' decisions were later overturned by the Appeals Chamber which interpreted 'proceedings' as only 'judicial proceedings' ${ }^{70}$ Accordingly, the Appeals Chamber found that the investigation is not a judicial proceeding which victims can participate in, but an 'inquiry conducted by the Prosecutor' ${ }^{71}$ Instead they can make 'representations' to the Prosecutor under Articles $15(2)$ and $42(1)$ on the investigation or their interests. ${ }^{72}$ Compared to the approach of the Pre-Trial Chambers, the Appeals Chamber's decision leaves victims in a far weaker position. Under the Appeals Chamber's approach, victims can still have an input into the investigative process, but there is no oversight of the prosecutorial selection of perpetrators or charges, or whether the Prosecutor is acting

\footnotetext{
63 Rule 92(2).

${ }^{64}$ See Elisabeth Baumgartner, Aspects of victim participation in the proceedings of the International Criminal Court, International Review of the Red Cross 90 (870) (2008) 409-440, p426-427.

65 Situation in DRC, ICC-01/04-101; and Situation in Uganda, ICC-02/04-101.

${ }^{66}$ Ibid ICC-01/04-101 para.63; followed in Situation in Darfur, Decision on the Applications for Participation in the Proceedings of Applicants a/0011/06 to a/0015/06, a/0021/07, a/0023/07 to a/0033/07 and a/0035/07 to a/0038/07, ICC-02/05-111-Corr, 6 December 2007, para.11.

${ }^{67}$ Ibid ICC-01/04-101, paras.57-58; and Situation in Uganda, ICC-02/04-101, paras.88-89.

${ }^{68}$ Ibid ICC-01/04-101, paras.58-59.

${ }^{69}$ Ibid para.70.

${ }^{70}$ Situation in $D R C$, Judgment on victim participation in the investigation stage of the proceedings in the appeal of the OPCD against the decision of Pre-Trial Chamber I of 7 December 2007 and in the appeals of the OPCD and the Prosecutor against the decision of Pre-Trial Chamber I of 24 December 2007, ICC-01/04-556, 19 December 2008, para.45; and Situation in the Republic of Kenya, Decision on Victims' Participation in Proceedings Related to the Situation in the Republic of Kenya, ICC-01/09-24, 3 November 2010, para.9.

${ }^{71}$ Ibid ICC-01/04-556, para.45.

72 Ibid. para.53. Confirmed in subsequent appeal of Situation in Darfur, Judgment on victim participation in the investigation stage of the proceedings in the appeal of the OPCD against the decision of Pre-Trial Chamber I of 3 December 2007 and in the appeals of the OPCD and the Prosecutor against the decision of Pre-Trial Chamber I of 6 December 2007, ICC-02/05-177, 2 February 2009.
} 
in their interests. ${ }^{73}$ Consequently, the Appeals Chamber's decision determines that in the investigation stage victims' role is to inform rather than to participate. This decision has been since followed by other Chambers. $^{74}$

The Appeals Chamber's decision is contradictory with other articles in the Rome Statute and the ability of the Prosecutor to represent victims' interests. First of all, Article 21(3), on the standards established in human rights law, requires victims to have 'full access and the capacity to take part in all the stages of the investigation'. ${ }^{75}$ The Appeals Chamber's position also contrasts with Article 15(3), which allows victims to make representations to the Pre-Trial Chamber on an investigation initiated by the Prosecutor. Moreover, the connection to the charges and perpetrators convicted before the Court will determine the scope of reparations victims will be able to claim. ${ }^{76}$ Upholding the independence of the Prosecutor to solely conduct investigations is in line with Article 42 and represents a more common law approach to criminal trials. ${ }^{77}$ However, entrusting the Prosecutor to respect the interests of victims in an investigation does not always work in practice, as demonstrated by the ad-hoc tribunals. ${ }^{78}$ This is evident at the ICC where VLRs have made a number of submissions to the Court as well as initiated proceedings during the trials to expand the limited charges made by the Prosecutor against an accused. ${ }^{79}$

By way of example, victims in the DRC situation sought to review the decision of the Prosecutor not to charge Jean-Pierre Bemba for the numerous crimes his militia committed in Ituri. ${ }^{80}$ Additionally, in the Kenyan case of Ruto et al the VLRs claimed that the Prosecutor had not conducted a meaningful investigation nor considered victims' interests. ${ }^{81}$ Both of these claims were dismissed by the Court on the basis of the independence of the Prosecutor. ${ }^{82}$ Accordingly, the Appeals Chamber may not have fully considered victims' interests in the investigation with sufficient weight, which is a crucial

\footnotetext{
${ }^{73}$ Article 53(1)(c).

${ }^{74}$ Prosecutor v Ruto, Kosgey, and Sang, Decision on the "Request by the Victims' Representative for authorisation to make a further written submission on the views and concerns of the victims", ICC-01/09-01/11-371, 9 December 2011, paras.16-17.

75 Gomes-Lund et al. (Guerrilha do Araguaia) v. Brazil, Merits, Reparations and Costs, Series C No 219, (IACtHR, 24 November 2010), para.257.

${ }^{76}$ Article 75(2), and Situation in Uganda, ICC-01/04-101, paras.50-53.

${ }^{77}$ McGonigle n.8, p226-227. See also Prosecutor v Muthaura, Kenyetta, and Ali, Decision on the Confirmation of Charges Pursuant to Article 61(7)(a) and (b) of the Rome Statute, ICC-01/09-02/11-382, 23 January 2012; and Prosecutor v Ruto, Kosgey and Sang, Decision on the Confirmation of Charges Pursuant to Article 61(7)(a) and (b) of the Rome Statute, ICC-01/09-01/11-373, 23 January 2012. As opposed to criminal court judges in civil law jurisdictions who are responsible for the investigation.

${ }^{78}$ See Binaifer Nowrojee, "Your Justice is Too Slow": Will the International Criminal Tribunal for Rwanda Fail Rwanda’s Rape Victims? In D. Pankhurst (ed.), Gendered Peace: Women's Struggles for Post-War Justice and Reconciliation, (Routledge 2007) 107-136.

${ }^{79}$ Such as Regulation 55 proceedings in the Lubanga case discussed in the following sub-section.

${ }^{80}$ Situation in DRC, Demande du représentant légal de VPRS 3 et 6 aux fins de mise en cause de Monsieur JeanPierre Bemba en sa qualité de chef militaire au sens de l'article 28-a du Statut pour les crimes dont ses troupes sont présumées coupables en Ituri, ICC-01/04-564, 30 June 2010. See HRW report n, p36-47.

${ }^{81}$ Ruto et al, ICC-01/09-01/11-367, 9 November 2011.

${ }^{82}$ Situation in DRC, Decision on the request of the legal representative of victims VPRS 3 and VPRS 6 to review an alleged decision of the Prosecutor not to proceed, ICC-01/04-582, 25 October 2010; and Prosecutor v Ruto et $a l$, Decision on the "Request by the Victims' Representative for authorisation to make a further written submission on the views and concerns of the victims", ICC-01/09-01/11-371, 9 December 2011, paras.16-17.
} 
juncture in determining the outcomes of truth, justice and reparations at later stages. While the Court has admitted victims' submissions for a review to be taken of the prosecution's decisions, the judges have not ordered such a review nor have they asked another impartial prosecutor to examine the decision, consistent with current EU best-practices. ${ }^{83}$

Of course we cannot divorce the realities of international criminal prosecution from human rights obligations, which must provide some leeway in deciding to prosecute or not. A high level of selectivity of perpetrators and charges is the norm in international criminal justice, due to the Court's purpose to prosecute and punish those most responsible for international crimes with its limited resources. ${ }^{84}$ Baumgartner suggests that this provides a symbolic function of condemning such crimes. ${ }^{85}$ However, this sits uneasily with human rights jurisprudence on the obligation to conduct investigations and prosecutions of those responsible for gross violations of human rights, in order to ensure an effective remedy to victims as well as to end impunity. In practical terms, issues of costs, access to sensitive investigations, disclosure, and protection of witnesses and evidence raise challenges as to victim participation in the investigation stage. However, victims would not be personally participating, but their professional legal representatives, who would only need access to confidential information during the investigation and a right of appeal of Prosecutor's decisions to the Court.

McGonigle questions whether the emphasis in human rights law on victim participation in the investigation, which is normally applied in the domestic level, should be applicable to the ICC. ${ }^{86}$ Aside from the Court's obligation to interpret the Rome Statute in light of international recognised human rights law in Article 21(3), victim participation is a necessary part of the ICC achieving its goals of ending impunity and delivering justice to victims under the broader heading of accountability. Human rights law has found that victim participation is a vital part of ensuring an effective investigation, which is necessarily connected to perceptions of legitimacy of the Court and the rule of law in ensuring individuals have a right to review executive decisions. Moreover, if the ICC is the 'high-water mark' for victims, and, in positive complementarity terms, is to provide exemplary practice for State Parties, it should be striving to ensure procedural best practices with the transparency of its investigations through the participation of victims as independent parties. Accusations that the first convictions of Thomas Lubanga and Germain Katanga failed to hold them responsible for sexual violence, despite it widespread occurrence in Ituri, suggests that the OTP did not conduct effective investigations into such crimes. $^{87}$

Accordingly, the ICC Prosecutor should be independent, but not unaccountable. There needs to be some oversight of their discretion to ensure victims' interests are being taken into account, thereby allowing local input into this important stage and to dispel some perceptions as the Court imposing

\footnotetext{
${ }^{83}$ Article 11, EU Directive 2012/29/EU.

${ }^{84}$ Baumgartner n.64, p437-438.

85 Ibid p438.

${ }^{86}$ McGonigle n.8, p341.

${ }^{87}$ See the new OTP Policy Paper on Sexual and Gender-Based Crimes, June 2014.
} 
justice on a society. That said victim-led prosecutions before the ICC would politicise the Court and undermine its impartiality. This is not what victim-orientated justice requires; rather it involves victims participating in proceedings which affect them and for the Court's judges to consider their interests. Victim participation in the investigation may be seen as undermining the fairness and impartiality of an investigation, but their role is not to collect evidence or select charges, which is the prerogative of the Prosecutor. Instead victims' rights should exist here in so far as they are able to review a decision by the Prosecutor not to prosecute, such as in national jurisdictions, and for the Court to examine whether this decision was adequately reached in light of the evidence, public interest and victims' interests in prosecuting. While it would be easy to say that the Prosecutor did not properly consider the interests of victims, the Court is obligated to review the decisions of the Prosecutor, thus placing the onus on the judges to remedy such situations, rather than the hubris of an independent prosecutor is an effective one ${ }^{88}$ The failure to allow greater victim participation in the investigation stage has had a knock on effect on the meaningfulness of victims' role in later stages.

\section{Participation in the trial}

Participation in the trial stage can offer victims the opportunity to have their interests considered by the Court in relation to clarifying the facts and determining the responsibility of the accused ${ }^{89}$ The VLRs have brought to light the context of victims' harm, the continued difficulties they face, their needs and expectations, and presented evidence on the culpability of defendants. VLRs have also made a number of imaginative applications to expand the charges against an accused during the trial proceedings to overcome the shortcomings of the Prosecution's case. In the Lubanga case, the VLRs attempted to use Regulation 55 to re-characterise the charges against the defendant to include sexual slavery, and cruel and inhumane treatment. ${ }^{90}$ Later in the same case, they sought to include victims who had suffered at the hands of the direct victims of the charges, i.e. child soldiers. ${ }^{91}$ Yet, the Court rejected all of these requests on the basis of the Prosecutor's independence.

During the trial of Lubanga, Trial Chamber I allowed victims to present evidence on these crimes, such as the documentation of sexual violence and other crimes committed by the defendant's militia in Ituri, despite not appearing in the charges. ${ }^{92}$ In addition, the Trial Chamber judges questioned

\footnotetext{
${ }^{88}$ Article 53(3)(b), Rome Statute.

89 Street Children case, para.227.

${ }^{90}$ Prosecutor v Lubanga, Joint Application of the Legal Representatives of the Victims of the Implementation of the Procedure under Regulation 55 of the Regulations of the Court, ICC-01/04-01/06-1891-tENG, 22 May 2009. Prosecutor v Lubanga, Clarification and further guidance to parties and participants in relation to the "Decision giving notice to the parties and participants that the legal characterisation of the facts may be subject to change in accordance with Regulation 55(2) of the Regulations of the Court", ICC-01/04-01/06-2049, 27 August 2009; Prosecutor v Lubanga, Judgment on the appeals of Mr Lubanga Dyilo and the Prosecutor against the Decision of Trial Chamber I of 14 July 2009 entitled 'Decision giving notice to the parties and participants that the legal characterisation of the facts may be subject to change in accordance with Regulation 55(2) of the Regulations of the Court', ICC-01/04-01/06-2205, 8 December 2009. See McGonigle n.8, p294-296.

${ }^{91}$ Lubanga, ICC-01/04-01/06-1813.

${ }^{92}$ Lubanga, ICC-01/04-01/06-T-145-Red3-ENG, 6 March 2009, p37; and Lubanga, ICC-01/04-01/06-T-193ENG, 17 June 2009, p75-77.
} 
witnesses on the prevalence of sexual violence against female child soldiers in Mr Lubanga's militai. ${ }^{93}$ The Chamber also permitted victims to 'tell their story' in narrative form, which included the details of these crimes thereby ensuring their documentation. ${ }^{94}$ In the Trial Chamber's final judgement $\mathrm{Mr}$ Lubanga was convicted of the charges of enlisting and conscripting children used in an armed conflict. This realised certain victims' interests in truth and justice through officially acknowledging and documenting their harm, condemning the crimes, and finding the defendant responsible. However, from the outset of the case had been criticised that the charges were too narrow, which the Court refused to change this in order to maintain the independence of the Prosecutor. ${ }^{95}$ As a result, the final judgement did not hold Mr Lubanga responsible for the other crimes committed by his militia despite the evidence presented before the Court. ${ }^{96}$

These efforts attest to the constraints of international criminal proceedings in trying to deliver justice to victims within its primary function of prosecuting and punishing perpetrators. ${ }^{97}$ The shortcomings of the charges could have been overcome at an earlier stage by modifying them in the pre-trial stage. ${ }^{98}$ Trial Chamber I instead suggested that it would give more weight to sexual violence and inhumane and degrading treatment in the determination of sentencing and reparations. ${ }^{99}$ This may offer some recognition and condemnation of the victims' suffering. Yet, the Court has not established the responsibility of Lubanga's militia for committing those crimes; therefore it does not satisfying victims' right to justice or truth.

With regards to truth, the judges have emphasised the role of victims in helping a Chamber to determine it through presenting evidence. ${ }^{100}$ For instance, in the Bemba case the VLRs 'helped the Chamber to understand relevant events, such as where they distinguished the use of Lingala by the accused and his militia in comparison to local languages. ${ }^{101}$ However, there is a danger that victims' interests could become secondary to the truth which the ICC is interested in, making them just functional to the Court's agenda. Moreover, it is hard to reconcile the Court's goal of determining the truth under Article 69(3) in allowing victims to participate, yet denying their requests to expand the charges against

\footnotetext{
${ }^{93}$ For instance, Lubanga, ICC-01/04-01/06-T-145-Red3, 6 March 2009, p79; and Lubanga, ICC-01/04-01/06-T194-ENG, 18 June 2009, p46-47.

${ }^{94}$ See Lubanga, ICC-01/04-01/06-T-225-Red2-ENG, 12 January 2010, p31; Lubanga, ICC-01/04-01/06-T-227Red3-ENG, 14 January 2010, p61; and Lubanga, ICC-01/04-01/06-T-230-Red2-ENG, 21 January 2010. See McGonigle n.8, p321-323.

95 NGO Joint Letter to the Chief Prosecutor of the ICC on Charges against Thomas Lubanga and DRC Investigation, 31 July 2006.

96 Ituri: Covered in Blood, Human Rights Watch (2003), p21-29.

${ }^{97}$ McGonigle n.8, p357-365.

${ }^{98}$ In the confirmation of charges hearing under Article 61(7)(c)(i).

${ }^{99}$ Lubanga, ICC-01/04-01/06-2842, para.630.

100 Based on Article 69(3) of 'request the submission of all evidence that it considers necessary for the determination of the truth.'. Lubanga, ICC-01/04-01/06-1119, para.108. Approved by the Appeals Chamber in Lubanga, ICC-01/04-01/06-1432, para.98.

${ }^{101}$ Marian Pena, Victim Participation at the International Criminal Court: Achievements Made and Challenges Lying Ahead, ILSA Journal of International and Comparative Law 16(2) (2009-2010) 497-516, p502 citing Bemba, ICC-01/05-01/08-T-12-ENG WT, 15 January 2009, p97-98.
} 
defendant to provide a more representative and truthful account of their crimes. This may further indicate that victim participation under Article 69(3) serves more the interests of the Court rather than victims.

A further area where victims' interests can be taken into account in determining outcomes is in guilty pleas, though none have yet arisen before the Court. ${ }^{102} \mathrm{~A}$ Chamber can order the prosecution to present additional evidence and witnesses, or continue the trial so as to provide a more complete presentation of the facts and determination of the defendant's responsibility. ${ }^{103}$ Such an approach is respectful of victims' interests in truth and justice. This is in comparison to the previous international criminal tribunals which neglected victims' interests in guilty pleas. ${ }^{104}$ However, a Chamber is not obligated to make such an order, and remains under its discretion, so it is questionable the extent to which the Court will consider victims' interests in this area.

\section{Participation in sentencing proceedings}

Sentencing of a perpetrator is supposed to punish them for the wrongfulness of the crime and the harm they have caused. As noted above, punishment in international criminal justice pursues a number of purposes, mainly retribution, but due to the scale of such crimes it cannot fully equate the harm caused and is therefore necessarily symbolic. ${ }^{105}$ Victims can pursue sentencing goals other than retribution, such as ensuring their security or reconciliation. The ICC allows victims to have some input into determining punishment as VLRs are able to make submissions to a Chamber. ${ }^{106}$ The Court can also take into account aggravating factors such as harm suffered by the victims and their families, their defencelessness, multiple victims, and discrimination, which is similar to the practice of the ICTY. ${ }^{107}$ Nevertheless, the use of victims' suffering as an aggravating factor reflects a retributive purpose of punishment by trying to ensure a proportional punishment, rather than incorporating a more local understanding of justice.

At the time of writing the Court had only issued two sentencing judgements in the Lubanga and Katanga cases. The parties' submissions and the Court's judgement in these cases offers an insight into the diverse approaches and purposes of victims in the sentencing of perpetrators before the ICC. In the Lubanga case, the Prosecutor's sentencing submission requested the Court to consider sexual violence and rape as an aggravating factor, despite the defendant not being convicted for them. ${ }^{108}$ Terming victims' suffering in these crimes as aggravating circumstance serves a retributive purpose, but fails to recognise fully their harm and to document the responsibility of the perpetrator. More importantly,

\footnotetext{
102 Article 65(4).

103 Ibid.

104 See Jayne N. Clark, Plea Bargaining at the ICTY: Guilty Pleas and Reconciliation, European Journal of International Law 20(2) (2009) 415-436.

105 Baumgartner n.54, p438.

106 Article 76 and Rule 143. Prosecutor v Lubanga, Scheduling order concerning timetable for sentencing and reparations, ICC-01/04-01/06-2844, 14 March 2012, para.3.

${ }^{107}$ Rules 145(1)(c) and 145(2)(b)(iii-v) RPE.

108 Prosecutor v Lubanga, Prosecution's Sentence Request, ICC-01/04-01/06-2881, 14 May 2012, para.30-34.
} 
sexual violence and rape are not circumstances, but crimes; terming them otherwise diminishes their seriousness. As can be seen by the VLRs' sentencing submissions in the Lubanga case, which made no reference to these crimes as aggravating factors, instead they emphasised the harm caused, as well as the vulnerability and age of the children used as soldiers. ${ }^{109}$

The Court found that despite not being charged, sexual violence and rape could be considered aggravating circumstances. ${ }^{110}$ As the Prosecutor did not present sufficient evidence to support such a claim, it was rejected by the majority of the Court. ${ }^{111}$ Instead the Chamber held that sexual violence and rape would be considered for reparations. ${ }^{112}$ Such an approach is contrary to human rights law, which stipulates that reparations are grossly insufficient substitutes for accountability. ${ }^{113}$ Judge Benito also dissented from the majority stating that sexual violence was an aggravating circumstance on the basis of the harm it causes to victims and their families, with sufficient evidence of it had been raised during the trial. ${ }^{114}$ On this basis Judge Benito believed that Mr Lubanga should serve 15 years in comparison to 14 years by the majority. ${ }^{115}$ Considering the seriousness of these sexual crimes, the addition of one year is symbolic and a more substantive sentence was expected from the victims. The first sentencing judgement of the Court evidences a retributive stance, by recognising that victims' harm could be used to increase the defendant's sentence. The inclusion of sexual violence and rape as an aggravating factor may indicate the Court trying to counteract the limited charges, but this is an inappropriate solution, which was not actually in the victims' interests as they wanted them to be recognised as separate crimes, not circumstances, which belittles such horrendous suffering.

In the Katanga sentencing judgment the Victims’ Legal Representatives noted the physical harm as well as the social and economic impact on victims caused by the crimes the defendant was convicted of. The Legal Representatives also highlighted the vulnerability of the victims, many of whom were women, children and the elderly; the particular cruelty of the crimes; and ethnic discrimination and perpetration of the crimes against the Hema community. ${ }^{116}$ Although the Chamber in its judgment found that sexual slavery and rape had occurred in Bogoro, Mr Katanga was not found criminally responsible for these crimes. ${ }^{117}$ As a result, the prosecution sought that such crimes should

${ }^{109}$ Prosecutor v Lubanga, Observations sur la peine pour le groupe de victimes V01, ICC-01/04-01/06-2880, 14 May 2012, and Observations du groupe de victimes VO2 Sur des éléments de preuve établissant des circonstances aggravantes ou des circonstances atténuantes des faits portés à la charge de l'accusé reconnu coupable, ICC-01/0401/06-2882, 14 May 2012.

${ }^{110}$ On the basis of Rule 145(1)(c)(i-iv), Prosecutor v Lubanga, Decision on Sentence pursuant to Article 76 of the Statute, ICC-01/04-01/06-2901, 10 July 2012, para.67.

${ }^{111}$ Lubanga ibid, para.75. The Court only considered the victims' age as reflecting the gravity of the offence, rather than as an aggravating circumstance, paras.77-78.

112 Ibid. para.76.

${ }^{113}$ McKerr, para.121; and Vladimir Romanov v Russia, App. No. 41461/02 (ECtHR, 24 July 2008), para.78.

114 ICC-01/04-01/06-2901, p41-52.

115 Benito dissent, ibid., para.23.

${ }^{116}$ Observations du représentant légal relatives à la fixation de la peine, ICC-01/04-01/07-3457-Red, 7 April 2014.

117 Jugement rendu en application de l'article 74 du Statut, ICC-01/04-01/07-3436, 8 March 2014 paras.10001023. 
be again taken into account as aggravating circumstances. ${ }^{118}$ While the Chamber took these issues into account for the suffering of victims, including social stigma victims of sexual violence suffer, but it was in the context of all crimes committed, in particular those which the defendant was convicted of. ${ }^{119}$ Nevertheless, the Court was sensitive to the loss and continuing harm suffered by victims, this was reflected in the aggravating circumstances. However, despite the victims calling for a long sentence and the Prosecutor for 22-25 years, Mr Katanga was sentenced to 12 years, with time spent in ICC detention, some five years, to be deducted. Given the scale of the crimes he and Mr Lubanga were found responsible for and impact on ethnic communities in Ituri, such sentences were relative light. ${ }^{120}$

In more general terms, a victim-orientated approach to sentencing could be through the use of mitigating circumstances. The Rules of the Court allow a reduction of a defendant's sentence if they make efforts to compensate victims. ${ }^{121}$ In the Lubanga case, the VLRs of group V01 in their sentencing submission suggested that an apology by Mr Lubanga should be considered a mitigating circumstance. This was felt to be important by the victims, because of the continuing divisions in Ituri and its potential to help repair their suffering. ${ }^{122}$ In Katanga the Chamber also acknowledged that remorse or apology of the convicted person could be a mitigating factor, provided it was genuine, but would be only a small factor. ${ }^{123}$ Although Mr Lubanga or Katanga did not apologise, it suggests a possible avenue for the Court to be responsive to victims needs beyond retribution, and provide a more contextual justice outcome, such as reconciliation. It would not be hard to think of other scenarios where engagement with a truth and reconciliation commission, traditional ceremonies or domestic reparation programmes by a defendant in making amends or remedying a victim's harm could be considered a mitigating circumstance. This approach could offer a more contextual and harmonising approach by the ICC with domestic transitional justice processes and goals of reparative justice, provided it is in victims' express interests.

\section{Participation in reparation proceedings}

Moving away from the criminal proceedings of the ICC is the novel reparation proceedings of the Court. Many critics of the ICC victim participation regime, discussed below, consider that the role of victims should be limited to reparation proceedings to avoid undermining the role of the prosecution or the rights of the defendant. You would be forgiven for thinking then that victims' interests at this stage of proceedings would be given more weight. However, at least in the first reparation decision by the Court in the Lubanga case, considering the lack of compromise needed in judicial decision making between the interests of the parties in reparations proceedings as it is victim-centred, it is surprising that victims'

\footnotetext{
118 Prosecution's Sentence Request, ICC-01/04-01/07-3455, 7 April 2014, para.9.

${ }^{119}$ Décision relative à la peine (article 76 du Statut), ICC-01/04-01/07-3484, 23 May 2014, para.91 and fn.92.

${ }^{120}$ Given that a robber in domestic UK law can face a life imprisonment.

121 Rule 145(2)(a)(ii).

${ }^{122}$ Lubanga, ICC-01/04-01/06-2880, paras.17-21.

123 ICC-01/04-01/07-3484, para.118.
} 
interests did not form the dominant consideration. Instead a more paternalistic approach, where despite victims' interests being represented, the judges supplement their reasoning for what they thought was best for the victims. This attitude is evident in the use of individual and collective reparations. ${ }^{124}$

Individual reparations are measures aimed at repairing the harm suffered by an individual, such as compensation or rehabilitation; collective reparations are directed at remedying the communal harm suffered by a group, community or people, and usually take a symbolic form, such as memorial or apologies. Trial Chamber I in the Lubanga reparation decision recognised that individual and collective reparations could be ordered concurrently. ${ }^{125}$ Significantly, it dismissed victims’ individual applications for reparation, and instead favoured collective reparations directed at helping child soldiers and their communities. ${ }^{126}$ This was on the basis that community-based reparations would be 'more beneficial and have greater utility than individual awards, given the limited funds available and the fact that this approach does not require costly and resource intensive verification procedures. ${ }^{127}$ Additionally, the Court was more inclined to make reparations on a community-basis in order to ensure that reparations to certain individuals would not cause them further victimisation within Ituri, as other victimised communities of the conflict were excluded for reparations. ${ }^{128}$

However, this was contrary to the wishes of the victims who advocated for both individual and collective reparations. ${ }^{129}$ It is important to note that victims argued against community reparations on the grounds that the community 'accepted this behaviour [the recruitment and use of child soldiers in the conflict] for the most part and supported the leaders who engaged in it. Many even collaborated. ${ }^{130}$ Accordingly, reparations ordered on a community-basis do not directly remedy the harm suffered by victims, and portrays the Court's reparation regime as symbolic. This may be the result of the judges in the Lubanga case interpreting the ICC reparations regime as serving a more reconciliation or restorative purpose than a remedial one, owing to the defendant being indigent, difficulties in ordering individual reparations to child soldiers of one community in Ituri, and having to rely on the Trust Fund for Victims. The judges may also be trying to overcome the shortcomings of the criminal trial and its limited charges by maximising the scope of beneficiaries of reparations to the community rather than specific individuals. Nonetheless, such an approach reduces the meaningfulness and effectiveness of reparations in responding to the needs of those most affected by these crimes.

\footnotetext{
${ }^{124}$ Although there are a number of other issues with this decision, see Moffett n.54.

125 Decision establishing the principles and procedures to be applied to reparations, ICC-01/04-01/06-2904, 7 August 2012, para. 220.

126 Ibid. para. 274.

127 Ibid.

${ }^{128}$ Ibid. paras. 240 and 244.

129 Lubanga, Observations on the sentence and reparations by Victims a/0001/06, a/0003/06, a/0007/06, a/00049/06, a/0149/07, a/0155/07, a/0156/07, a/0162/07, a/0149/08, a/0404/08, a/0405/08, a/0406/08, a/0407/08, a/0409/08 , a/0523/08, a/0610/08, a/0611/08, a/0053/09, a/0249/09, a/0292/09, a/0398/09 and a/1622/10, ICC01/04-01/06-2864-tENG, 18 April 2012; and Observations du groupe de victimes VO2 concernant la fixation de la peine et des réparations, ICC-01/04-01/06-2869, 18 April 2012.

${ }^{130}$ Ibid. ICC-01/04-01/06-2864-tENG, para. 16.
} 
This decision is currently being appealed by victims on these grounds, but it stands in stark contrast to the regional human rights courts' decisions which have proactively aimed to ensuring victims' harm is effectively remedied. While detractors could argue that the ICC is a criminal court, the decision making of the judges has to be questioned as to whether they are actually considering the interests of the victims before them or trying to appeal to wider macro perceptions of the Court, in effect playing politics in trying to offer remedy to victims beyond the charges. Such an approach is understandable given the limited charges in the case. Yet it undermines the notion of redress for those victims before the Court, and could weaken the resolve upon state to deliver remedies to all victims of international crimes within its jurisdiction, instead being reliant on the ICC to act as a 'saviour'. The reparations decision has impacted other victims' perceptions of the Court in meaningfully responding to their interests. This is apparent in the Kenyan case of Ruto and Sang, whereby at least 47 victims have pulled out of participating at the Court. One of predominate issues they cited for pulling out was that reparations would be ordered collectively, such as the construction of a hospital, meaning that perpetrators who continue to live near victims would be able to benefit from the harm they caused. ${ }^{131}$ It remains to be seen if the Court will rectify this stance, and place the emphasis on states to deliver reparations to victims beyond the charges against the defendant (reparative complementarity), ${ }^{132}$ so that the Court can remedy the harm of victims' in the cases before it.

\section{Participation as victim-orientated justice}

Victim-orientated justice is about ensuring that the ICC is responsive to the needs of victims and reaches a fair balance in assessing the differing interests before it. In interpreting fairness and balancing the interests of the parties, the Court has on a number of occasions recognised that it is not limited to the prosecution and defence, but also includes 'respect for the procedural rights of victims. ${ }^{133}$ Yet, in comparison to victim participation in national courts, such as partie civile or Nebenklage, victims before the ICC have a more limited form of participation under Article 68(3), as they do not have the right to initiate an investigation, broader powers of questioning, or a right of appeal. ${ }^{134}$ Similarly at the ECCC, victims are able to appeal decisions and to ask for prosecutorial decisions to be reviewed. Furthermore, EU countries are moving towards recognising victims' right to review prosecutor's decisions not to

\footnotetext{
131 Prosecutor v Ruto and Sang, Common Legal Representative for Victims' Comprehensive Report on the Withdrawal of Victims from the Turbo area by Letter dated 5 June 2013, ICC-01/09-01/11-896-Corr-Red, 5 September 2013, para.12. The letter was based on the wishes of 93 victims -47 who had their participation status confirmed in the case, with 13 whose status is unclear, and 33 outside the scope of the case. There were some 628 victims participating as of December 2013.

132 See Moffett n.54.

133 Situation in DRC, Décision relative à la requête du Procureur sollicitant l'autorisation d'interjeter appel de la décision de la Chambre du 17 janvier 2006 sur les demandes de participation à la procédure de VPRS 1, VPRS 2, VPRS 3, VPRS 4, VPRS 5 et VPRS 6, ICC-01/04-135, 31 March 2006, para.38; Situation in Uganda, Decision on the Prosecution's Application for Leave to Appeal the Decision on Victims' Applications for Participation a/0010/06, a/0064/06 to a/0070/06, a/0081/06 to a/0104/06 and a/0111/06 to a/0127/06, ICC-02/04-112, 19 December 2007, para.27.

${ }^{134}$ See Doak n.13, p310.
} 
prosecute, something which the ICC judges have retreated from doing in order to maintain the separation of their power from the independence of the prosecution. The ability of other courts and tribunals to give more extensive right to victims brings into question whether the ICC has reached the correct balance with the defendant's rights and the role of the Prosecutor.

In light of the preceding, there are two problems with the current victim participation regime at the ICC which arise as it is costly, and largely symbolic in its assurance of justice for victims. With regards to the first of these, victim participation has also been criticised for being both 'time-consuming and resource intense' ${ }^{135}$ In October 2012, it was reported that the legal aid costs for the defence in all cases from 2006-2012 amounted to €11.51 million, whereas in the same period legal aid for victims was to the sum of $€ 15.85$ million. ${ }^{136}$ Schabas suggests that victims would benefit more if they have been given the money spent on legal representatives as reparations instead, considering the small amount of money likely to available for reparations. ${ }^{137}$ As already alluded to, victim participation at the ICC is largely symbolic as victims are only allowed to participate if they do not interfere with the interests of the prosecution or rights of the defendant. Moreover, they have a very minimal impact on determining outcomes. With no right of appeal, victims are unable to challenge the Prosecutor's selection of perpetrators and charges, or decisions by the Court which fail to consider their interests. This is contrary to human rights law which protects victims' right to an effective procedural remedy. This underscores their weaker position in comparison to the other parties. It may be worth considering future alternatives to remedy the current shortcomings of the ICC victim participation regime.

\section{Time for a new approach in considering victims' interests at the International Criminal Court?}

Central to the challenge of incorporating victims within the International Criminal Court is to try to reconcile its retributive purpose with the interests of victims who can seek a broader construction of justice. As Judge Wyngaert has stated, 'It may be too much to expect from the ICC to be a retributive (fighting impunity) and a restorative mechanism at the same time. ${ }^{, 138}$ A number of commentators have suggested that victims' interests before the Court should be diverted into the Trust Fund for Victims, reparations or other services. ${ }^{139}$ McGonigle finds that the judges at the ICC have through interpretation expanded the rights of victims at the expense of defendant's rights. ${ }^{140}$ In order to better protect the rights

\footnotetext{
${ }^{135}$ Håkan Friman, Participation of Victims in the ICC Criminal Proceedings and the Early Jurisprudence of the Court, in G. Sluiter and S. Vasiliev (eds.), International Criminal Procedure: Towards a Coherent Body of Law, (CMP Publishing 2009) 205-236, p236.

${ }^{136}$ Report of the Committee on Budget and Finance on the work of its nineteenth session, ICC-ASP/11/15, 28 October 2012, para.90.

${ }_{137}$ William A. Schabas, The International Criminal Court at ten, Criminal Law Forum 22(3) (2011), 493-509, p501.

${ }^{138}$ Christine Van den Wyngaert, Victims before International Criminal Courts: Some views and concerns of an ICC Trial Judge, Case Western Reserve Journal of International Law 44 (2012) 475-496, p492.

${ }^{139}$ Schabas n.131.

${ }^{140}$ McGonigle n.8, p360.
} 
of the defendant, she proposes that the Court should focus more on victims' service-related rights rather than procedural ones. Service-related rights would ensure victims are informed and able to provide information to the Court, but prevented from participating in proceedings. ${ }^{141}$ However, such an approach removes the contextual link of the Court with the situation country and those most affected by the crimes. Additionally, terming victims' rights as services would reinforce their discretionary nature, rather than legal entitlement, thereby further diminishing the weight of their interests in judicial decision making.

Wyngaert argues that victim participation slows down the Court's proceedings, preventing the ICC from fulfilling its retributive purpose. She also finds that victims' 'procedural' right to truth and justice do not necessarily mean they should participate in proceedings, but should instead their interests should be addressed by a Reparations Commission within the Trust Fund for Victims, thereby removing victims completely from the Court. ${ }^{142}$ This position dismisses victims' interests in criminal proceedings, and conflates their interests in truth and justice with reparations, which the Court itself has at length sought to distinguish. As outlined in the first section, the realisation of victims' substantive rights requires their input into proceedings, with participation the most effective way to ensure their interests are independently advocated. Moreover, excluding victims from proceedings undermines the drafters' intentions to deliver justice to victims, beyond retribution, so as to ensure that the work of the ICC is not abstract, but has meaning on the ground, particularly in light of the experience of the ad-hoc tribunals. The suggestions by Wyngaert, McGonigle and others seem to take a step backwards in the development of victims' role in international criminal justice, and could further alienate the ICC from affected communities and victims as the Court's primary beneficiaries.

That said, notions of fairness and due process are critical components to perceptions of legitimacy of the ICC, which has been brought into disrepute with the rights of defendants, notwithstanding victims' interests. In the recent Katanga judgment Judge Wyngaert in her dissent from the majority noted that given the delays in trial proceedings, changes in the characterisation of the facts, and acquittal of his co-accused Mathieu Chui on the lack of sufficient evidence presented by the prosecution, together undermined the accused's right to a fair trial, stating that,

'Considerations about procedural fairness for the Prosecutor and the victims and their Legal Representatives, while certainly relevant, cannot trump the rights of the accused. After all, when all is said and done, it is the accused - and only the accused - who stands trial and risks losing his freedom and property. In order for a court of law to have the legal and moral authority to pass legal and moral judgment on someone, especially when it relates to such serious allegations as international crimes, it is essential, in my view, to scrupulously observe the fairness of the proceedings and to apply the standard of proof consistently and rigorously. It is not good enough that most of the trial has been fair. All of it must be fair. ${ }^{143}$

\footnotetext{
${ }^{141}$ Ibid p363.

${ }^{142}$ Wyngaert n.138, p495. See also Salvatore Zappalá, The rights of victims v. the rights of the accused, Journal of International Criminal Justice 8(1) (2010) 137-164, p140; and McGonigle n.8, p361.

${ }^{143}$ Prosecutor v Katanga, Minority Opinion of Judge Christine Van den Wyngaert, 7 March 2014, ICC-01/0401/07-3436-AnxI, para.311.
} 
This understanding of fairness reflects the different views of judges as to fairness and how the balance between victims, defence and prosecution should be struck. Rather than excluding victims entirely from the equation, victim participation at the ICC needs to be rethought to improve its effectiveness. Together the problems identified with victim participation in the previous sub-section of being costly and symbolic, come from a lack of a coherent understanding on the purpose of victim participation or general role within the ICC. The problem is not victims themselves, but having an effective way for their interests to be presented and considered before the Court. The issue of cost brings home the need to ensure value for money, not only for the Court and the Assembly of State Parties, but for the victims themselves, that their time and energy is more effectively channelled so that the ICC can be as responsive as possible to their needs. If concerns of cost and ineffectiveness are reasons to reduce or limit victim participation, such a rollback would undo the progress and experience already gained by the ICC.

A clear understanding of how victims' interests can be taken into account within the framework of the ICC as victim-orientated justice could guide judges' interpretation. This could ensure greater consistency between decisions and reduce inequality. This would involve recognising victims as independent parties who can participate in investigations, and have their interests more substantively considered during trial and sentencing proceedings. Attaching more weight to victims' interests in the investigation and sentencing stage would enable them to have a more meaningful role in proceedings that can be more responsive to their needs. In turn, having a more coherent understanding of victim participation could minimise time and resources spent on determining modalities and appeals. This is likely going to require judges or the ASP to create formalised rules of procedure to streamline or 'harmonise'144 future victim participation in cases, based on settled jurisprudence established by the Court, such as certain modalities, but would still allow some flexibility in each case.

\section{Conclusion}

The start of this article quoted the UN Secretary General Kofi Annan stating that the Court's 'overriding interests must be that of the victims and the international community'. Although the victim provisions of the ICC may be innovative in international criminal justice, heralding them as a 'high-water mark' is misleading when compared to the more advanced jurisprudence of regional human rights and national courts. It needs to be remembered that the criminal proceedings of the ICC are retributive in nature. While it is unrealistic to assume that victims' interests would dominate the ICC and become a victimcentred court, the drafters did intend that one of the purposes of Court was to deliver justice to victims. The construct of victim-orientated justice developed in the first section does provide some insight into how the ICC can be responsive to victims’ needs whilst balancing them against other interests.

${ }^{144}$ See Vasiliev n.39. 
However when examining the Court's proceedings, the adherence to victims' interests and needs in proceedings is less evident. The provisions in the Rome Statute do offer victims some form of procedural justice by allowing them to present their interests, in contrast to previous tribunals. Yet this has not resulted in the ICC being responsive to victims' interests in substantive outcomes. Even though the Court has recognised victims' rights to truth, justice and reparations, their input is not sufficiently considered in the determination of outcomes, particularly in the investigation. Where victims' interests are adhered to is when they do not conflict or infringe on the rights of the defendant or the independence of the Prosecutor, namely certain protection measures, such as closed sessions. ${ }^{145}$ Accordingly, this gives the impression that victims' role in the proceedings of the ICC is symbolic, as their role does not impinge upon the fact-finding or determination of justice by the other parties and the judges. Reparations at the ICC could offer a more victim-centred justice, or at least one that is more likely to satisfy their substantive needs. But as the sub-sections on the investigation and reparation stages found, the scope of reparations and victims which can benefit from them are inevitably constrained by decisions by an international prosecutor with no transparent local input from victims, which in the end necessarily limits the potential of reparations at the ICC. Furthermore the first reparation decision of the Court suggests that the judges recognise this limitation, but try to overcome it through promoting more collective reparations, but this is counterintuitive to the interests of the victims participating before the Court.

While this does not necessarily mean that victim participation in the Court's criminal proceedings should be excluded, it does require reconsideration on moving forward in developing a more effective participatory regime. This may require a more formalised participation regime, victimorientated complementarity through domestic mechanism that enable victim participation (which in itself would improve the public transparency of investigations and trials), and to find novel approaches in sentencing and reparation stages in meeting victims' interests in justice beyond retribution. Furthermore, in improving the legitimacy of the Court in the eyes of affected communities and victims, greater effort is needed to acknowledge their perspective. Otherwise these important stakeholders will disengage with the Court as a costly and symbolic exercise of international justice. Considering victims' interests does not require their interests to dominate judicial decision making, rather it is about taking their views and concerns into account in shaping the outcomes of the Court.

\footnotetext{
${ }^{145}$ Prosecutor v Katanga and Chui, Decision on the Set of Procedural Rights Attached to Procedural Status of Victim at the Pre-Trial Stage of the Case, ICC-01/04-01/07-474, 13 May 2008, paras.21-22. For a fuller discussion see Moffett n.6, Chapter 3.
} 